\title{
Correction to: Optimization along families of periodic and quasiperiodic orbits in dynamical systems with delay
}

\author{
Zaid Ahsan $($ ) Harry Dankowicz · Jan Sieber
}

Published online: 16 December 2019

(C) The Author(s) 2019

\section{Correction to: \\ Nonlinear Dyn \\ https://doi.org/10.1007/s11071-019-05304-y}

The article Optimization along families of periodic and quasiperiodic orbits in dynamical systems with delay, written by Zaid Ahsan, Harry Dankowicz, and Jan Sieber, was originally published electronically on 5 November 2019 without open access. With the author(s)' decision to opt for Open Choice, the copyright of the article changed on 16 December 2019 to (C) The Author(s) 2019 and the article is forthwith distributed under the terms of a Creative Commons Attribution-NonCommercial 4.0 International License (https://creativecommons.org/licenses/by-nc/ $4.0 /$ ), which permits any non-commercial use, sharing, adaptation, distribution, and reproduction in any medium or format, as long as you give appropriate credit to the original author(s) and the source, provide a link to the Creative Commons licence, and indicate if changes were made.

Open Access This article is licensed under a Creative Commons Attribution 4.0 International License, which permits use, sharing, adaptation, distribution and reproduction in any medium or format, as long as you give appropriate credit to the original author(s) and the source, provide a link to the Creative Commons licence, and indicate if changes were made. The images or other third party material in this article are included in the article's Creative Commons licence, unless indicated otherwise in a credit line to the material. If material is not included in the article's Creative Commons licence and your intended use is not permitted by statutory regulation or exceeds the permitted use, you will need to obtain permission directly from the copyright holder. To view a copy of this licence, visit http://creativecommons.org/licenses/ by $/ 4.0 /$.

Publisher's Note Springer Nature remains neutral with regard to jurisdictional claims in published maps and institutional affiliations.

The original article can be found online at https://doi.org/10. 1007/s11071-019-05304-y.

\section{Z. Ahsan $(\varangle) \cdot$ H. Dankowicz}

Department of Mechanical Science and Engineering, University of Illinois at Urbana-Champaign, Urbana, USA e-mail: zaid2@illinois.edu

J. Sieber

College of Engineering, Mathematics and Physical Sciences, University of Exeter, Exeter, UK 